\title{
THE PHYSICAL EXAMINATION OF TWO THOUSAND CASES OF NEUROSIS
}

\author{
BY \\ H. G. McGREGOR \\ (Medical Specialist, Military Hospital for Neurosis)
}

(Received 7TH SePtember, 1943)

THE material of this paper consists of 2,288 consecutive admissions to a military hospital for neurosis. Selection has taken place before arrival, because only those cases which are considered to have a good chance of rehabilitation are recommended. Age ranges between 18 and 49 with a maximum number at the age of 23 . Length of service ranges between 6 weeks and 17 years, with a preponderance at $2 \frac{1}{2}$ to 3 years. Only a few old soldiers with 10 or more years service appear in the series.

The proportion of N.C.Os. to other ranks are: Sergeants, Corporals, Lance-Corporals, Privates, in the ratio of $2,2,1,11$.

\section{Organic Disease}

Of the 2,288 cases, 78 (or 3.4 per cent.) were thought to be suffering from organic disease as the basis of their symptoms.
Epilepsy

and Bronchitis

Arthritis of Spine

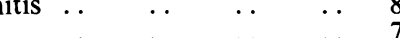

with early renal involvement ...

$\begin{array}{lllllll}\text { Narcolepsy } & \ldots & \ldots & \ldots & \ldots & \ldots & 6\end{array}$

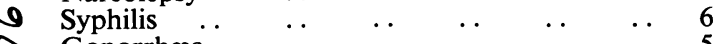

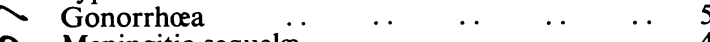

$\begin{array}{llllll}\text { Meningitic sequelæ } & \ldots & \ldots & \ldots & \ldots & 4\end{array}$

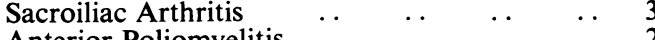

Anterior Poliomyelitis $\begin{array}{lllll} & \ldots & \ldots & \ldots & 2\end{array}$

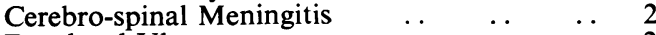

$\begin{array}{llllll}\text { Duodenal Ulcer } \ldots & \ldots & \ldots & \ldots & \ldots & 2\end{array}$

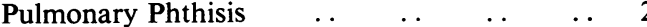

Sub-clinical malaria $\quad \ldots \quad$.

$\begin{array}{llllll}\text { Addison's Anæmia } & \ldots & \ldots & \ldots & \ldots & 1\end{array}$

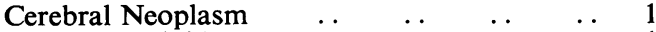

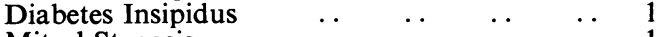

$\begin{array}{lllllll}\text { Mitral Stenosis } & \ldots & \ldots & \ldots & \ldots & \ldots & 1\end{array}$

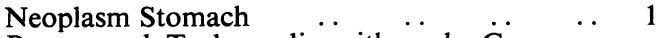

Paroxysmal Tachycardia with early Coronary

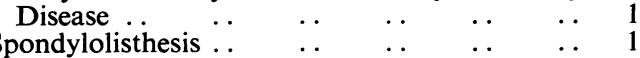

$$
\begin{array}{lllllll}
\text { TOtAL } & \ldots & \ldots & \ldots & \ldots & & \\
78
\end{array}
$$

The list is a reminder that many diseases are mistaken in the first instance for neurosis and can only with difficulty be distinguished after investigation. Almost all predominant or common neurotic symptoms are also symptoms of organic disease. For instance, the 7 cases of hypertension all presented themselves as cases of headache, and were separated from a large collection of anxiety headaches. The spinal conditions likewise were weeded out from a very large number of " backaches." One of the cases of anterior poliomyelitis (onset 6 weeks previously and happily mild) was sent in as an hysterical paralysis of the leg; one of the cases of meningitis arrived in a confused state under escort, with a diagnosis of hysterical amnesia; the case of diabetes insipidus was admitted as a diurnal enuresis.

In addition to the instances in which an established disease was present, a variety of lesser organic conditions were found which contributed to the production of symptoms. Sepsis was prevalent, especially of the accessory nasal sinuses ( 6 per cent. of all cases), and dental sepsis ( $4 \frac{1}{2}$ per cent. of all cases); an abundance of minor disabilities was present in the shape of pes planus, pes cavus, varicocoele, varicose veins, hernia, boils, errors of refraction, nævus, mole, deviated nasal septum, alopecia, seborrhœic manifestations, psoriasis, etc. In all, 35 per cent. of cases showed some contributory or minor ailment.

\section{Neurosis}

The remaining cases were those in which the organic element was minimal. They numbered 2,210. They may be grouped in the following way:-

\begin{tabular}{|c|c|c|c|c|c|}
\hline Anxiety State & . & $\therefore$ & . & $\cdots$ & \\
\hline Dyspepsia & .. & $\cdots$ & .. & $\cdots$ & \\
\hline Effort Syndrome & . & .. & . & . & . \\
\hline Rheumatism & $\cdots$ & $\ldots$ & .. & $\ldots$ & \\
\hline Hysteria $\ldots$ & .. & .. & .. & . & . \\
\hline Headache .. & & & . & $\ldots$ & . \\
\hline Post Concussion & Neuro & & . & .. & \\
\hline Enuresis $\ldots$ & . . & . & . & . & .. \\
\hline Fugue & .. & . & .. & . & $\ldots$ \\
\hline Stammer & . & . & . & .. & $\cdots$ \\
\hline Syncopal Attacks & & . & . & . & $\cdots$ \\
\hline Homosexualism & .. & $\ldots$ & . & $\ldots$ & $\ldots$ \\
\hline Psychosis & . & $\cdots$ & . & .. & $\cdots$ \\
\hline Sleep Walking & . & .. & .. & .. & . \\
\hline Night Blindness & . & $\ldots$ & .. & . & . \\
\hline Tic. & & & . & . & .. \\
\hline Obsessive Compu & lsive & Neur & & .. & .. \\
\hline Pruritus & .. & . & . & . & .. \\
\hline Constipation & .. & $\cdots$ & . & $\cdots$ & 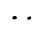 \\
\hline Overbreathing Te & $\tan y$ & . & .. & . & $\cdots$ \\
\hline Alcohol Addictio & & . & .. & $\ldots$ & \\
\hline
\end{tabular}


This is not a psychiatrist's classification. It is a rough grouping according to the most prominent symptoms complained of by the patient.

Those psychosomatic cases in which there appeared to be a definite somatic location for psychogenic symptoms, effort syndrome, dyspepsia, anxiety headache and rheumatism, are the main consideration in this paper. They appear to form a definite group by reason of their somatic symptoms, yet reference to the psychiatric diagnoses in these cases shows that they consist of precisely the same mixture of conditions as the other groups-namely, anxiety neurosis, psychopathic personality, emotional instability, and hysteria.

\section{Blood Pressure}

Our conception of " normal" blood pressure is founded upon certain classical studies of large numbers of subjects (Symonds, 1923; Janeway, 1913; Alvarez, 1923; Robinson and Brucer, 1939) which established the belief that a systolic pressure as high as $150 \mathrm{~mm}$. $\mathrm{Hg}$. is to be regarded as abnormal at all ages, and a diastolic of 100 as probably always pathological.

It is well known that blood pressure varies considerably with emotion. The systolic blood pressure may vary as much as $50 \mathrm{~mm}$. $\mathrm{Hg}$. under the influence of emotion and isolated readings of 160 and 170 are not uncommon (Fahrenkamp, 1931, and Mohr, 1925). Hence it is to be expected that neurotics, whose emotional apparatus may be particularly sensitive, would show more frequent and greater variations than normal. This is the case; and our conception of what is a normal blood pressure reading is considerably modified thereby.

Of the total 2,210, 1,901 (86 per cent.) had systolic pressures of 140 or less and diastolics of 90 or less. This leaves 309 (or 14 per cent.) who had systolic or diastolic pressures greater than 140/90. The figures noted were sometimes very much larger, and varied between 140 to 190 systolic, and 90 to 120 diastolic. Those cases in which the readings were unusually high were re-examined after ten minutes rest, or longer, on the couch. Usually a lower figure was recorded. If it was not, the patient was re-examined the next day in the same manner. .

With the exception of 7 cases it was possible in every instance to obtain diastolic readings below 100 , whilst the systolic fell to a more normal level, usually, though not always, to 140 or less.

Three groups thus separate themselves:-

1. 1,901 patients with habitual systolic and diastolic pressures of $140 / 90$ or less.

2. 302 with systolic and diastolic pressures greater than 140/90, in whom rest and confidence reduced the diastolic to below 100 and the systolic to a lower level than at first.

3. 7 cases in which rest and confidence, though producing some lowering, never reduced the diastolic reading to below 100 .

100 cases from Group 1; 150 cases from Group 2; and all 7 cases from Group 3 were investigated by:-

1. Retinoscopy.
2. Urine analysis and microscopy of centrifuged deposit.

3. Concentration and dilution test, judged by specific gravity after fasting or drinking.

4. Urea clearance.

All 7 cases in group 3 gave abnormal findings (Table I). In none of the other cases was abnormality found.

Table I.-Group III (7 Cases)

\begin{tabular}{c|c|c|c|c|c}
\hline & & $\begin{array}{c}\text { Maximum } \\
\text { urinary } \\
\text { Re. gr. } \\
\text { afteries } \\
\text { after 12 } \\
\text { hours } \\
\text { fluid fast }\end{array}$ & $\begin{array}{c}\text { Sp. gr. } \\
\text { maximum } \\
\text { after } \\
1,500 \text { c.c. } \\
\text { water }\end{array}$ & $\begin{array}{c}\text { Urea } \\
\text { clearance } \\
\text { per cent. }\end{array}$ & B.P. \\
\hline $\mathrm{N}$. & - & 1,015 & 1,005 & Cs 52 & $\frac{150}{110}$ \\
$\mathrm{~N}$. & - & 1,019 & 1,002 & Cm 48 & $\frac{165}{105}$ \\
$\mathrm{~N}$. & - & 1,017 & 1,008 & Cs 42 & $\frac{170}{110}$ \\
$\mathrm{~N}$. & - & 1,019 & 1,008 & Cs 56 & $\frac{160}{105}$ \\
Marked & - & 1,013 & 1,010 & Cs 48 & $\frac{180}{110}$ \\
silver \\
wire
\end{tabular}

From this it may be concluded that a systolic blood pressure reading up to almost $200 \mathrm{~mm}$. Hg. may be within normal limits, provided the level is not constantly maintained and provided that the diastolic reading is not in excess of 100. A diastolic reading which exceeds 100 is almost certainly pathological.

Further, it has been found almost impossible to judge from the patient's behaviour whether or not his blood pressure reading will depart from usual levels. Before estimating the blood pressure every patient was given an arbitrary rating from 1 to 4 according to whether he appeared calm and undisturbed or showed objective signs of anxiety (such as restlessness, depressed and unhappy facies, twitching, tremor, excessive sweating, pallor, dry disorderly hair, irritability). Table II shows that these four

\section{TABLE II}

(All blood pressure readings represent systolic level at orginal interview.)

\begin{tabular}{|c|c|c|c|c|c|c|c|}
\hline & $\begin{array}{c}1 . \\
\text { Sys- } \\
\text { tolic } \\
140 \text { or } \\
\text { less }\end{array}$ & $\begin{array}{c}2 . \\
140- \\
150\end{array}$ & $\begin{array}{c}3 . \\
150- \\
160\end{array}$ & $\begin{array}{c}4 . \\
160- \\
170\end{array}$ & $\begin{array}{c}5 . \\
170- \\
180\end{array}$ & $\begin{array}{c}6 . \\
180- \\
190\end{array}$ & Totals \\
\hline $\begin{array}{c}1 . \\
\text { Normals } \\
2 . \\
3 . \\
4 . \\
\text { Most } \\
\text { anxious }\end{array}$ & $\begin{array}{l}592 \\
391 \\
317\end{array}$ & $\begin{array}{l}51 \\
23 \\
41\end{array}$ & $\begin{array}{l}12 \\
25 \\
17\end{array}$ & $\begin{array}{l}12 \\
16 \\
11\end{array}$ & $\begin{array}{l}6 \\
5 \\
5\end{array}$ & $\begin{array}{l}4 \\
5 \\
5\end{array}$ & $\begin{array}{l}677 \\
465 \\
395\end{array}$ \\
\hline Totals & 1,901 & 142 & 74 & 49 & 22 & 15 & 2,203 \\
\hline
\end{tabular}


groups are distributed amongst the different blood pressure levels.

Thus, although the number of patients with high blood pressure readings is smaller than that with low ones, the number of objectively anxious patients with high readings is not, as might be expected, greater than those normals who show high readings (vertical column 6); the number of normals showing normal readings is about the same as that of anxious patients (vertical column 1). Normals and nervous patients are distributed throughout the whole blood pressure scale (vertical column 7). There is, therefore, no relation between blood pressure height and objectively recognizable anxiety.

\section{Exercise Tolerance Test}

Unreliability in the cardiac exercise tolerance test has been noted amongst cases of effort syndrome. One hundred and fifty men who showed the typical symptoms of effort syndrome (cardiac discomfort on exertion, breathlessness, dizziness, sweating, tremor, etc., etc.) were examined. In every case physical findings were normal, blood pressure was within normal limits, cardiograph tracing normal, $\mathrm{Hb}$. over 85 per cent. Twenty-nine of these patients showed a deceleration rate in excess of 3 minutes after the standard exercise of mounting a chair 12 times. They were then placed in a physical training class and given very light physical training with no jumping, vaulting, parallel-bar work or running. Most of the exercises were carried out sitting or lying down. After an interval of two days in this class their exercise tolerance was again tested, by running once round the gymnasium. In every case a normal exercise tolerance was recorded.

The improvement in tolerance cannot have resulted from any work done in the gymnasium, because the time was insufficient, nor was the type of exercise carried out likely to lead to any improvement. These men had all appeared nervous during the first examination. It would, therefore, seem that when the patient had had time to settle down and was in a more carefree atmosphere, any nervous factors that may have prolonged the tachycardia after exertion were not operating.

This group was compared with one hundred and fifty physically fit men going through a " Hardening Course," whose neurosis had never consisted of symptoms of effort syndrome, but of enuresis, constipation, pruritus, etc., which had no relation to exertion. In hospital they were occupied on physical training or strenuous physical exertion all day. This group had likewise been tested on admission to hospital, and afterwards in the gymnasium. In no case was a deceleration time noted in excess of two minutes.

Pulse rate, cardiac output, blood pressure, etc., are well known to be markedly affected by psychic stimuli (Braun, 1932; Fahrenkamp, 1931; Grollman, 1932). Deceleration times in excess of two minutes in cases of effort syndrome have been noted by Friedlander and Freyhoff, 1918, and by Wood, 1941. Meakins and Wilson, 1918, have shown that persons in whom sudden emotion causes unusual acceleration of pulse rate when resting have a poor effort tolerance. The discrepancies in effort tolerance test noted here may reasonably be supposed to result from emotional factors, though whether the original abnormal finding was, in fact, due to emotion is not certain.

\section{The Problem of Somatic Location}

Great interest centres around the question, "What factors influence the somatic location of psychogenic symptoms.",

The first impression gained from observation of the four main groups of psycho-somatic illness, is of the superficial similarity of the personalities encountered, in spite of varied symptoms and psychopathology. For instance, in addition to the main cardiac, dyspeptic, or rheumatic symptoms of each group, they all reported a number of other symptoms common to the four groups. Table III shows the incidence of these symptoms. The four groups are compared with the group of anxiety states which showed no main somatic localization of symptoms.

TABle III.-Distribution of Symptoms Over All GROUPS

\begin{tabular}{|c|c|c|c|c|c|}
\hline $\begin{array}{l}\text { Symptoms } \\
\text { complained } \\
\text { of in addition } \\
\text { to main } \\
\text { complaint }\end{array}$ & $\begin{array}{c}313 \\
\text { cases } \\
\text { effort } \\
\text { syn- } \\
\text { drome }\end{array}$ & $\begin{array}{c}424 \\
\text { cases } \\
\text { dys- } \\
\text { pepsia }\end{array}$ & $\begin{array}{c}223 \\
\text { cases } \\
\text { rheuma- } \\
\text { tism }\end{array}$ & $\begin{array}{c}122 \\
\text { cases } \\
\text { head- } \\
\text { ache }\end{array}$ & $\begin{array}{c}464 \\
\text { cases } \\
\text { anxiety } \\
\text { state }\end{array}$ \\
\hline $\begin{array}{l}\text { Breathlessness } \\
\text { Dizziness } \\
\text { Sighs } \\
\text { Trembling } \\
\text { Flushes } \\
\text { Fatiguability } \\
\text { Nervousness } \\
\text { Sweating .. } \\
\text { Paraesthesiæ } \\
\text { Dry mouth } \\
\text { Insomnia } \\
\text { Annorexia .. }\end{array}$ & $\begin{array}{l}\text { per } \\
\text { cent. } \\
95 \\
64 \\
47 \\
72 \cdot 5 \\
50 \\
90 \\
67 \\
75 \\
48 \\
43 \\
12 \\
15\end{array}$ & $\begin{array}{l}\text { per } \\
\text { cent. } \\
21 \\
54 \\
36 \\
63 \\
22 \\
84 \\
75 \\
63 \cdot 5 \\
11 \\
50 \\
27 \\
78\end{array}$ & $\begin{array}{l}\text { per } \\
\text { cent. } \\
33 \cdot 4 \\
24 \\
12 \\
54 \\
89 \\
72 \\
12 \\
73 \\
83 \\
9 \\
31 \\
10\end{array}$ & $\begin{array}{c}\text { per } \\
\text { cent. } \\
13 \\
91 \\
10 \\
18 \\
32 \\
75 \\
8 \\
14 \\
50 \\
15 \\
25 \\
9\end{array}$ & $\begin{array}{c}\text { per } \\
\text { cent. } \\
48 \\
54 \\
49 \\
92 \\
41 \\
68 \\
57 \\
79 \\
26 \\
43 \\
52 \\
48\end{array}$ \\
\hline
\end{tabular}

An analysis of the case-histories to determine the precipitant of the breakdown, or, where there was no obvious immediate precipitant, of the conditions under which the breakdown took place, revealed no specific incident peculiar to one group. Moreover, the variety of precipitating causes were relatively few as is shown in Table IV. Physical trauma or the conditions of action held an unimportant place compared with severe training-e.g., O.C.T.U. or Commando- or with domestic worry, occupational worry or boredom, and it was remarkable how many patients complained that army discipline was the condition they could not tolerate. Boredom, particularly, was a fertile source of neurosis, especially when combined with some real or fancied grievance, and the high proportion of cases in artillerymen seemed to be related to employment on lonely antiaircraft or searchlight sites. In all four groups the 
previous history showed that a large proportion had had symptoms before enlistment, either continuously or at some isolated stage in their life (see Table V).

Table IV.-Precipitating Cause of Breakdown

\begin{tabular}{|c|c|c|c|c|}
\hline & $\begin{array}{l}\text { Effort } \\
\text { Syn- } \\
\text { drome }\end{array}$ & $\begin{array}{l}\text { Dys- } \\
\text { pepsia }\end{array}$ & $\begin{array}{c}\text { Rheuma- } \\
\text { tism }\end{array}$ & $\begin{array}{l}\text { Head- } \\
\text { ache }\end{array}$ \\
\hline $\begin{array}{l}\text { Trauma Aircraft } \\
\text { crash, blown up, }\end{array}$ & per cent. & per cent. & per cent. & per cent. \\
\hline $\begin{array}{l}\text { other accidents. } \\
\text { Whilst in action. }\end{array}$ & 0 & 2 & 5 & 15 \\
\hline $\begin{array}{l}\text { Whilst in action. } \\
\text { Training, Com- } \\
\text { mando,O.C.T.U., }\end{array}$ & 2 & 0 & 0 & 2 \\
\hline Assault Course. . & 10 & 8 & 7 & 6 \\
\hline $\begin{array}{l}\text { Domestic worry.. } \\
\text { Unsuitable occu- }\end{array}$ & 7 & 9 & 2 & 21 \\
\hline 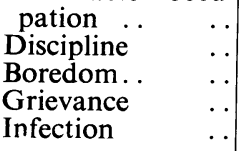 & $\begin{array}{r}11 \\
22 \\
45 \\
0 \\
3\end{array}$ & $\begin{array}{r}12 \\
21 \\
34 \\
14 \\
0\end{array}$ & $\begin{array}{l}11 \\
20 \\
28 \\
15 \\
12\end{array}$ & $\begin{array}{r}15 \\
13 \\
10 \\
5 \\
12\end{array}$ \\
\hline
\end{tabular}

TABle V.-Previous History of Breakdown

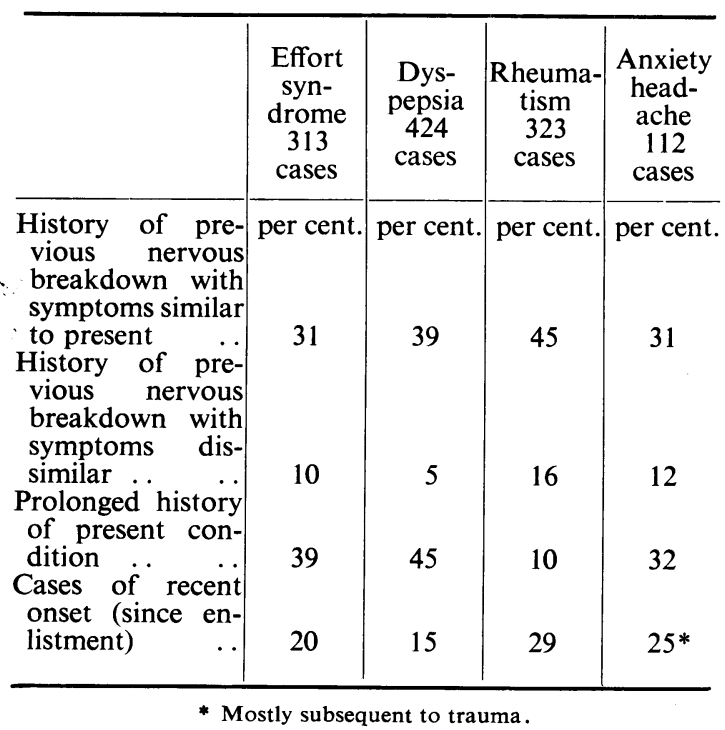

Tables IV and V, therefore, show that these soldiers developed nervous symptoms under the influence of one of the precipitants listed, but they had also reacted in a similar manner before service though they had continued in spite of them in the conditions of civilian life.

The "trigger" conditions of infection, or emotional or physical strain, which precipitate the neurosis appear to be scattered fairly equally throughout the four groups of psycho-somatic illness, but they do not account for the nature of the symptoms, which seems to depend upon other factors. These seem to be multiple; and they combine to produce an individual who will react in a certain way to a condition of stress, no matter what that condition may be. They may be physical or psychological, and are included in the following list:-

\section{Physical}

1. Heredity.

2. Constitution.

3. Previous Disease.

4. Physique-Personality.

5. Habitual Function, e.g. Habitual respiratory types of Golla and Antonvitch.

6. Autonomic Balance.

7. Endocrine Balance.

\section{Psychological}

1. Early Association.

2. Suggestion.

3. Symbolism.

4. Organ Inferiority.

These are only a few of the factors which determine a neurosis and they are those which seem to direct the location of the symptoms of a neurosis with somatic manifestations. There are many others which also influence emotional development during growth and so help to determine whether a person will become neurotic. Those which determine when he will break down are mainly environmental.

It is not possible in a short paper of this kind to discuss each factor in detail and to illustrate from this series. I propose, therefore, to discuss only some of them and to leave the remainder, to be dealt with more fully in a later publication.

\section{Somatic Factors}

1. Heredity.-The high incidence of cardiac neurosis in families of patients suffering from cardiac neurosis is well recognized (Wood). This, however, applies to other neuroses as well. The point is that not only is a family history of neurosis common in neurotics, but that, once neurosis becomes established in a family, succeeding generations tend, if they suffer from neurosis at all, to suffer from a similar one (see Table VI).

Table VI.-Family History of Neurosis

\begin{tabular}{|c|c|c|c|c|c|}
\hline & \multirow[b]{2}{*}{$\begin{array}{l}\text { Effort } \\
\text { Syn- } \\
\text { drome }\end{array}$} & \multirow[b]{2}{*}{$\begin{array}{c}\text { Dys- } \\
\text { pepsia }\end{array}$} & \multicolumn{2}{|c|}{ Rheumatism } & \multirow[b]{2}{*}{$\begin{array}{l}\text { Head- } \\
\text { ache }\end{array}$} \\
\hline & & & $\begin{array}{l}\text { Pro- } \\
\text { bably } \\
\text { or- } \\
\text { ganic }\end{array}$ & $\begin{array}{l}\text { Pro- } \\
\text { bably } \\
\text { func- } \\
\text { tional }\end{array}$ & \\
\hline $\begin{array}{l}\text { Family history of } \\
\text { similar neurosis } \\
\text { Family history of } \\
\text { nerves - location } \\
\text { not necessarily the }\end{array}$ & $\begin{array}{c}\text { per } \\
\text { cent. } \\
52\end{array}$ & $\begin{array}{c}\text { per } \\
\text { cent. } \\
41\end{array}$ & $\begin{array}{c}\text { per } \\
\text { cent. }\end{array}$ & $\begin{array}{c}\text { per } \\
\text { cent. } \\
17\end{array}$ & $\begin{array}{c}\text { per } \\
\text { cent. } \\
43\end{array}$ \\
\hline same $\quad \ldots \quad \ldots$ & 15 & 12 & 15 & - & 38 \\
\hline
\end{tabular}

2. Constitutional.-All patients are placed in a physical training group on arrival in hospital, and 75 per cent. of patients do physical training during the whole of their stay. They are divided into four 
classes of graded severity and a note has been kept of the performance of these 1,072 psychosomatic cases. The result shows that 71 per cent. start in the light grades and never achieve any increase in their grade. To compare the classes at work is most instructive. The two strenuous classes are full of energetic, vigorous men, who work and play with a will and join in all recreational games; the light classes are sluggish, lackadaisical, and uninterested.

Some of the acute and recent cases of anxiety recover their natural physical energy as their mental condition improves, but generally the anergia of the light classes is not due to lack of training or of exercise which will gradually be overcome, for, as stated above, the majority do not improve. Nor is it related to the medical category, for 69 per cent. of these men were in Army Category A1 on physical grounds. The physical training instructors complain that "there's not a bit of good in any of them "- meaning physical strength, co-ordination, agility; yet testing has shown that these patients as a whole are of considerably higher intelligence than a cross-section of the rest of the Army. Their disability in this direction consists of a fundamental timidity or apprehensiveness.

An inquiry into the previous histories of the entire series showed that 25 per cent. had never indulged in sports or vigorous exercise all their lives, and that a further 30 per cent., though they played games whilst at school, had lost interest or given them up in late adolescence or early in adult life. This constitutional incapacity, therefore, is not necessarily an incapacity for effort, because many of them had indulged in sport as youngsters and the condition was not confined to the effort syndrome cases. Wood (1941), investigating a series of 200 cases of effort syndrome, concluded that

" in childhood these patients are timid and delicate; they cling too long to their mother's skirts. They evade as much as possible, with the help of friendly coughs and colds; kindly doctors and soft mothers are at hand to protect them.... But they may not develop effort intolerance until they are ten or eleven years old, or not until much later. The case histories suggest that parental influence causes timidity and character inferiority, but not effort intolerance."

This is the impression gained from the series under review here; and a study of their case-histories as taken at the original examination confirms the fact that a very large majority of them have been timid evaders at heart for the greater part of their lives, certainly since adult age.

3. Incidence of Previous Disease or Trauma.The incidence of antecedent disease as a predisposing factor in illnesses in which emotional factors play a large part has been stressed previously (1938), particularly so in asthma, for in a series of 150 cases reported elsewhere, 25 per cent. showed a history of antecedent pulmonary disease. In other words, antecedent disease leaves its mark both upon the organ it attacks and upon the patient's mind. Asthma, however, is a rare disease in this hospital and is not included in the present series.
It is interesting that trauma which long antedates the appearance of symptoms and which has often been fogotten in the interval seems to play the same part in some cases as disease does in others-for instance, the rheumatism and headache cases. The incidence of previous trauma as a factor in rheumatism and backache has been stressed previously. In the present series remote trauma was very common, particularly in the cases of backache and headache It is noticeable that the trauma was commonly in the same position as the subsequent neurotic symptom. The series is controlled against a group of 100 cases of hernia. In the controls the traumatic factor was non-existent.

TABle VII.-InCidence of Remote Trauma

\begin{tabular}{|c|c|c|c|c|c|}
\hline \multicolumn{4}{|c|}{ Rheumatism 223 cases } & \multirow[b]{2}{*}{$\begin{array}{l}\text { Head- } \\
\text { ache } \\
112 \\
\text { cases }\end{array}$} & \multirow[b]{2}{*}{$\begin{array}{c}\text { Hernia } \\
\text { controls } \\
100 \\
\text { cases }\end{array}$} \\
\hline $\begin{array}{l}\text { Back- } \\
\text { ache } \\
75 \\
\text { cases }\end{array}$ & $\begin{array}{l}\text { General- } \\
\text { ized } \\
\text { rheuma- } \\
\text { tism } 82 \\
\text { cases }\end{array}$ & $\begin{array}{c}\text { Limbs } \\
54 \\
\text { cases }\end{array}$ & $\begin{array}{c}\text { Neck } \\
12 \\
\text { cases }\end{array}$ & & \\
\hline $\begin{array}{c}22 \\
(21 \mathrm{per} \\
\text { cent.) }\end{array}$ & $\begin{array}{l}6 \\
\text { ( } 7 \text { per } \\
\text { cent.) }\end{array}$ & $\begin{array}{c}8 \\
\text { (15 per } \\
\text { cent.) }\end{array}$ & - & $\begin{array}{c}32 \\
(29 \text { per } \\
\text { cent.) }\end{array}$ & $\begin{array}{c}1 \\
\text { (1 per } \\
\text { cent.) }\end{array}$ \\
\hline
\end{tabular}

A typical history may be quoted:-

Bdr. H., aged 28. He was swept off a lorry by bough of tree in 1940-injuring his back. He was in hospital with bruises in lumbar region for ten days. There was no fracture.

He returned to duty and remained well until 1942 when he began reporting sick with backache. He was referred to the orthopædic specialist by his M.O. with a diagnosis of lumbago. The Orthopædic Specialist could find no signs of organic disease and referred him to a psychiatrist. The patient was eventually admitted to hospital.

On examination he appeared a somewhat dull and heavy looking man complaining of pain on bending or when marching. His spine was supple and no localized tenderness or fibrositic nodules were detected. No evidence of focal infection was found. X-ray of spine was normal.

For the previous 18 months the patient had been an A.A. gunner, to which arm he had been transferred from the infantry with the whole of his regiment. He disliked the work, had been moved from one part of the country to another, had stood what little action he had seen fairly well, but had been bored by the work for which he felt he was not suited. He did not get on well with the other N.C.Os. and prior to his breakdown had had his stripes taken away for insolence to a Warrant Officer. The report from his C.O. stated him to have good qualities when he liked to use them.

His work record previous to joining the Army was not a particularly good one. There had been many changes of occupation and two periods of unemployment. He had no fixed trade and had been employed mostly as a builder's labourer. At school he had been slightly below the standard for his age.

Comment.-In this case it is noticeable how the prolonged period of dissatisfaction with the patient's army occupation and the difficulties with his superiors culminated in the appearance of neurotic symptoms. Having regard to his earlier civilian history this was perhaps to be expected. Faced 
with a similar situation in civilian life he would in all probability have undergone another change in occupation or another workless period. In the Army that solution was not possible, so he solved the difficulty by the production of symptoms in a part of the body which earlier experience of injury had impressed upon his mind as already damaged.

The production of symptoms by remote trauma is not exactly the same thing as the traumatic incidents immediately preceding the onset of symptoms. Trauma may act both as a predisposing factor and as a precipitating stimulus to the neurosis. This is especially so in the case of severe traumatic experiences such as bomb or shell explosions. Many soldiers who went through severe shell fire in 1940 did not develop a neurosis until two years later. The precipitating cause in these cases was sometimes another traumatic incident, but was often some completely different kind of stimulus.

4. Physique-Personality.-No systematic study of physique-personality has been made in the present series of cases, but it is included in the discussion for the purpose of delineating more fully the picture of psycho-somatic ætiology. The operation of this joint factor is best illustrated by the dyspeptic group. The theory has been gaining ground that peptic ulcer is simply the later stage of an emotionally or physically conditioned central process-a process which may give rise to disturbances of gastric secretion and motility. Alkan (1930), for instance, in discussing the pathogenesis of peptic ulcer, distinguishes an an-ulcerous and an ulcerous stage, and some observations by Wittkower (1931) tend to confirm this view. If this is so, then those factors which predispose to the occurrence of ulcer might be expected to be operative in an-ulcerous dyspepsia. In this connection it would seem that studies on constitution by Ruhmann (1926); Draper (1930); Draper and Touraine (1932); Cushing (1932); Einhorn (1930); Hurst and Stewart (1929); and Davies and Wilson (1937) relating to the common occurrence of gastric ulcer in the asthenic-obsessional are of great moment.

It will be interesting to see whether further studies will show that peptic ulcer is in fact a mere incident in an underlying neurotic dyspepsia. In a large number of cases in the present series it was almost impossible to diagnose clinically the presence or absence of ulcer in a dyspeptic, and the symptomatology does not seem to alter greatly with the appearance of an ulcer, at any rate in its early stages. Both of the patients in whom an ulcer was found to be present were regarded, on clinical grounds, as being free from organic lesion. Of the remaining 424 cases, 21 were thought to have gastric or duodenal ulcers and were subsequently shown to have a normal gastric mucosa. Further evidence is required both upon the proportion of functional dyspeptics who develop an ulcer later and upon patients with a confirmed ulcer which was preceded by neurotic manifestations.
This paper may be concluded by repeating that only a few of the physical aspects of psycho-somatic ætiology have been discussed and none of the psychological ones. I have stated or implied that these factors do nothing but direct the location of the symptom once the ultimate causes of neurosis have produced a favourable psychological status. The causal factors in neurosis, however, cannot be separated into isolated groups as easily as that, for the individual factors are interdependent, but such a scheme may help in the understanding of these disorders, though it may be discarded as knowledge increases.

\section{Summary}

1. 2,288 consecutive admissions to a Military Hospital for neurosis have been considered.

2. 3.4 per cent. of the cases had an organic disease. These have been briefly described.

3. The mean blood pressure of the remainder was found to be higher than the accepted normal.

4. Anomalous results of exercise tolerance test which were found are probably due to nervous factors.

5. A list of the factors which may lead to the location of psycho-somatic symptoms is given, and some of these factors, illustrated from the present series, are discussed.

My thanks are due to the Commanding Officer and staff of the hospital for their co-operation in the examination of patients.

\section{REFERENCES}

Alvarez, W. C. (1923). Arch. intern. Med., 32, 17.

Alkan, L. (1930). Anatomische Organkrankheiten aus seelischer Ursache, Stuttgart.

Braun, L. (1932). Herz und Angst, Vienna.

Cushing, H. (1932). Surg. Gynec. Obstet., 55, 1.

Davies, D. T., and Wilson, A. T. M. (1937). Lancet, 2, 1353.

Draper, G., and Touraine, G. A. (1932). Arch. intern. Med., 49, 616.

Draper, G. (1930). Disease and the Man, London.

Einhorn, M. (1930). Amer. J. med. Sci., 179, 259.

Fahrenkamp, K. (1931). Der Herzkranke, Stuttgart.

Friedlander, A., and Freyhoff, W. L. (1918). Arch. intern. Med., 22, 693.

Grollmann, A. (1932). Cardiac Output of Man in Health and Disease, London.

Hurst, A. F., and Stewart, M. J. (1929). Gastric and Duodenal Ulcer, London.

Janeway, T. C. (1913). Arch. intern. Med., 12, 755.

McGregor, H. G. (1938). Emotional Factor in Visceral Disease, London.

Meakins, J. C., and Wilson, R. M. (1918), Heart, 7, 17.

Mohr, F. (1925). Psychophysiche Behandlungsmethoden, Leipzig.

Norris, G. W., Bazett, H. C., and McMillan, T. M. (1927) Blood Pressure, 4th Edit., Philadelphia.

Robinson, S. C., and Brucer, M. (1939). Arch. intern. Med., 64, 409.

Ruhmann, W. (1926). Der Ulcuskranke, Berlin.

Symonds, B. (1923). J. Amer. Med. Ass., 80, 232.

Wittkower, E. (1931). Verh. dtsch. Ges. inn. Med., 43, 68.

Wood, P. (1941). Brit. med. J., 1, 767, 805. 